\title{
“TEMOS O DEVER SAGRADO DE DEFENDER O QUE É NOSSO": A TRAJETÓRIA E A LUTA POLÍTICA DE MARÇAL DE SOUZA TUPÃ'I
}

\author{
José Henrique Prado ${ }^{1}$ \\ Antonio Hilário Aguilera Urquiza²
}

RESUMO: Marçal de Souza Tupa'i nasceu em 1920 no município de Ponta Porã/MS, em um contexto histórico onde seu povo sofria por um recente contato com a sociedade nacional, sendo vítima, junto com os demais Guarani e Kaiowa de Mato Grosso do Sul de um regime tutelar do Estado brasileiro, que tinha como intuito "desindianizar" esses povos, através de práticas de confinamento em pequenas áreas, desrespeitando o modo de vida dessas populações. O presente trabalho revisita dados de campo coletados em meados dos anos de 2010 e tem como objetivo apresentar uma breve trajetória da vida de Marçal de Souza, liderança da etnia Guarani assassinada em 1983, cujo o nome ainda reverbera em meio aos movimentos indígenas de Mato Grosso do Sul.

Palavras-chave: Liderança Indígena. Guarani e Kaiowá. Mato Grosso do Sul. Marçal Tupã’i.

NHE'E BYKY: Marçal de Souza Tupa'i onase 1920 Punta Porã'pe/MS, oiko asy i'hente kuerande, umi governo mboruvixa, onhangareko asy entero vetea, ombojoá ava kuera yvy mixi’pe. Ojejuká Marçal de Souza tenondeta Guarani, 1983.

Ayvu nhe 'e: Avá tenondeta. Guarani e Kaiowá. Mato Grosso do Sul. Marçal Tupã'i.

RESUMEN: Marçal de Souza Tupa'i nació en 1920 en el municipio de Ponta Porã / MS, en un contexto histórico donde su pueblo sufría por un reciente contacto con la sociedad nacional, siendo víctima, junto con los demás Guaraní y Kaiowa de Mato Grosso do Sur de un régimen

\footnotetext{
${ }^{1}$ Graduado em Ciências Sociais UFMS, Mestre em Antropologia Sociocultural pela UFGD. Professor substituto da Universidade Federal de Mato Grosso do Sul (UFMS) campus de Naviraí. E-mail: prado.jhenrique@gmail.com.

${ }^{2}$ Doutor em Antropologia pela USAL e orientador do trabalho. Professor efetivo da UFMS do curso de Ciências Sociais e nos programas de mestrado de Antropologia Social e de Direitos Humanos da mesma instituição. hilarioaguilera@gmail.com.
} 
tutelar del Estado brasileño, que tenía como objetivo "desindianizar" a esos pueblos, a través de prácticas de confinamiento en pequeñas áreas, desatendiendo el modo de vida de esas poblaciones. El presente trabajo revisita datos de campo recogidos a mediados de los años 2010 y tiene como objetivo presentar una breve trayectoria de la vida de Marçal de Souza, liderazgo de la etnia guaraní asesinada en 1983, cuyo nombre aún reverbera en medio de los movimientos indígenas de Mato Grosso Del sur.

Palavras Clave: Liderazgo Indígena. Guaraní y Kaiowá. Mato Grosso do Sul. Marçal Tupã’i.

ABSTRACT: Marçal de Souza Tupa'i was born in 1920 in the municipality of Ponta Porã / MS, in a historical context where his people suffered from a recent contact with the national society, being victim, along with the other Guarani and Kaiowa of Mato Grosso do Sul a tutelary regime of the Brazilian State, which had the intention of "deindividing" these peoples, through practices of confinement in small areas, disrespecting the way of life of these populations. This paper revisits field data collected in the middle of 2010 and aims to present a brief trajectory of the life of Marçal de Souza, leadership of the Guarani ethnic group killed in 1983, whose name still reverberates among the indigenous movements of Mato Grosso southern.

Keywords: Indigenous Leadership. Guarani and Kaiowá. Mato Grosso do Sul. Marçal Tupã’i.

\section{As origens}

O nosso caminho não será mais rosas. Talvez muitos de nós devam escrever a nossa História Indígena com o sangue, como tem acontecido a irmãos nossos. Temos o dever sagrado de defender o que é nosso. (Marçal de Souza Tupã'i, 1977)

Apesar das drásticas consequências da perda da terra, os Guarani e Kaiowá apresentam uma surpreendente capacidade de adaptação e ressignificação dos empecilhos deste violento processo subumano de cerceamento dos seus direitos de reprodução cultural. Os povos indígenas, cada um à sua maneira, vão reagindo de forma diversificada às frentes de ocupação de seus territórios, e consequentemente ao inevitável contato com as "frentes de expansão".3 Segundo Brand (1997, p. 08-10) os Guarani e Kaiowá se adaptam e reconstituem em lugares diversificados seus territórios.

A partir desta questão, contextualizamos a luta de Marçal de Souza Tupã'i, a qual pode ser sinalizada como um momento importante da resistência dos indígena na busca de reconstruir o ñande reta (nosso território) do povo Guarani e Kaiowá, desta forma buscando

\footnotetext{
${ }^{3}$ Definida pelo antropólogo Roberto Cardoso de Oliveira como sendo "A noção de 'frente', acrescida à de 'expansão', indica claramente a característica dinâmica do fenômeno que se investigar. É a sociedade nacional, através de seus segmentos regionais, que se expande sobre áreas e regiões cujos únicos habitantes são as populações indígenas. Mas esse processo de expansão não é conduzido ao acaso. Interesses econômicos o conduzem, motivando as populações nele envolvidas" (1972, p. 98).
} 
"reconstruir, re-organizar e recriar suas aldeias enquanto tekoha" (BRAND, 1997, p. 09). O pesquisador em questão continua seu pensamento afirmando que: o acento maior não está na ocupação e na presença de um determinado lugar, e sim na possibilidade de "reconstruir" uma relação específica com a terra.

O nascimento de Marçal de Souza Tupã'i - e, em linhas gerais, o de todas as crianças - definitivamente é algo de muito valor para seu povo, pois, "o mundo ao redor não é, para os índios, um puro espaço neutro, mas o prolongamento vivo do universo humano: o que se produz neste afeta sempre aquele" (CLASTRES, 1995, p.20). Marçal será durante sua vida um grande defensor dos direitos dos povos indígenas no Brasil, sempre utilizando a palavra como uma forte ferramenta de resistência contra o desrespeito gerado pela política opressora do Estado nacional e das elites agrárias em relação a estes.

Marçal de Souza nasceu em um contexto de conflitos cada vez mais violentos, como podemos verificar aqui:

A ação dos "bugreiros" era implacável. Esses jagunços, especializados em matar índio, isto é, "bugre" (daí o nome), eram contratados por fazendeiros da região, em sua maioria sulistas, no intuito de "limpar" a área, para mais facilmente ocupar as terras (PREZIA, 2006, p.21).

Esta passagem refere-se ao relato realizado por Kurt Nimuendaju da chacina de um grupo com mais de 50 Kaiowá que habitava a beira do Rio Papagaio (MT) em 1900 (cf. PRÉZIA, 2006). É nesse contexto de violência e opressão por parte das frentes de ocupação, que nasce Marçal de Souza, batizado como Tupã'i no ritual de batismo dos Guarani. Vem ao mundo em 1920 na localidade de Rincão de Júlio na região do atual município de Ponta Porã, na divisa com o Paraguai, no atual estado de Mato Grosso do Sul. Neste período, o confinamento $^{4}$ realizado pela ação tutelar ${ }^{5}$ do órgão indigenista oficial (SPI) já estava em processo.

\footnotetext{
${ }^{4}$ Confinamento é considerado como o processo histórico de demarcação de Reservas Indígenas pelo SPI, que se seguiu da ocupação do território dos Guarani e Kaiowá por frentes não-indígenas, forçando a transferência dessas populações (indígenas) para dentro dos espaços definidos pelo Estado como os únicos lugares que deveriam ser considerados adequados para a posse indígena. Indica, portanto, o processo de progressiva passagem de um território indígena amplo, fundamental para a viabilização de sua organização social, para espaços exíguos, demarcados e definidos a partir de referenciais externos, tendo como perspectiva a integração dessa população à "comunhão nacional", prevendo-se sua progressiva transformação em pequenos produtores ou assalariados a serviço dos empreendimentos econômicos regionais (BRAND, 1997).

${ }^{5} \mathrm{O}$ conceito de "poder tutelar" é definido no estudo do antropólogo Antonio Carlos de Souza Lima; em que Lima demonstra que as práticas do Estado em relação aos povos indígenas mantinham em vista a ideia de assimilação, integração e a inserção desses povos em meio a sociedade nacional como trabalhadores rurais, dessa forma, agindo através de práticas embasadas em uma visão e uma ação de cunho colonialista, ou seja, que reproduzia a ideia de metrópole e de colônia, sendo a sociedade nacional relacionada a primeira enquanto que os
} 
Meu nome é Tupã'i.

Este é meu nome, meu verdadeiro nome. Meu nome de batismo pelo ritual Guarani. Quando era pequeno fui batizado por cacique. Não sou homem grande, sou pequenininho. Sou da tribo Guarani. Falo meu idioma e meu dialeto com carinho (TETILA, 1994, p. 13).

Sua família mudou-se em 1923 para a aldeia Tey’kuê no município de Caarapó-MS, de lá sua família mudou-se para a reserva de Dourados e depois retornaram para Tey’i Kuê onde Tupã' $i^{6}$ ao ser picado por uma cobra venenosa, teve que ser transferido para a reserva de Dourados para receber atendimento adequado na Missão Evangélica Caiuá.

Após quase um ano de recuperação viu-se órfão ${ }^{7}$, e fica morando no orfanato recémconstruído da Missão Evangélica Caiuá, a Ñhanderoga (nossa casa). No ano de 1932, já com 12 anos, Marçal vai viver em Campo Grande-MS, junto com a família presbiteriana que o havia adotado, onde pôde realizar seus estudos até o sexto ano do ensino fundamental na Escola Oswaldo Cruz, permanecendo em Campo Grande até 1938. Logo após, acompanhando sua família não-índia adotiva vai morar em Recife-PE, pois o Sr. Olímpio, arrimo da família que o adotara, trabalhava para o exército e foi transferido para o nordeste, onde permanece até 1940. Segundo Édina, ${ }^{8}$ filha de Marçal, durante esse período ele teve oportunidade de estudar, porém tinha que exercer serviços domésticos para a família que o adotara:

\begin{abstract}
Esse pessoal dessa família trouxe ele pra Campo Grande, porque ele era militar e foi transferido pra cá, pra dar continuidade nos estudos dele... tanto é que ele foi matriculado na escola Oswaldo Cruz onde ele estudou até o sexto ano... só que ele teve que abandona o curso porque ele virou empregado doméstico adolescente.(...) E essa trajetória de vida ele foi vendo o outro modo de vida, o dos não-índio... só que isso refletiu nele de forma diferente da de muitas outras pessoas... ele foi vendo com um outro olhar, um olhar comparativo, como que as comunidades indígenas viviam e como que a sociedade não-indígena vivia...e isso daí foi aguçando nele a consciência de luta, ele não se acomodou... em cima das leituras que ele fazia, ele lia muito, ele lia bastante.
\end{abstract}

povos indígenas se relacionariam a segunda. Cf. LIMA, Antonio C. de Souza. Grande Cerco de Paz: poder tutelar, indianidade e formação do estado no Brasil. Petrópolis: Vozes, 1995.

${ }^{6}$ Após conversas com indígenas das etnias Guarani e Kaiowá no decorrer da pesquisa e também em consultas bibliográficas (verificar TETILA, 1994 e PREZIA, 2006) pudemos constatar que o termo Tupã'i pode ser traduzido para o português como "pequeno Deus".

${ }^{7}$ Benedito Prezia (2006, p. 26) afirma que Marçal de Souza Tupã’i ficou órfão aos seis anos, já José Laerte Cecílio Tetila (1994, p. 14) afirma que foi "com cerca de oito anos". Por esses desencontros na bibliografia disponível é possível afirmar que mesmo após este trabalho os dados sobre os anos iniciais da vida de Marçal de Souza permanecem ainda com muito pouca exatidão, como é também a referência sobre as causas da morte de seus pais, onde Tetila (1994, p. 14) não dá nenhuma explicação sobre o motivo e Prezia (2006, p. 26) afirma que eles "devem ter morrido de alguma doença infecciosa, tão freqüente na época".

${ }^{8}$ Entrevista concedida a José Henrique Prado em 30 de Junho de 2010 na cidade de Campo Grande. 
Retorna em 1940 para a Reserva Indígena de Dourados já como um pregador do evangelho cristão, pois a "educação presbiteriana marcou-o muito, sobretudo do ponto de vista religioso" (PREZIA, 2006, p. 27). Devido a sua grande capacidade performática ${ }^{9}$ de uso da palavra, inicia uma prática de pregação nas aldeias da região. "Para o guarani, 'a religião é a palavra inspirada' e seguramente não deveria haver muita diferença entre a 'inspiração indígena' e a 'inspiração evangélica' (PREZIA, 2006, p. 27). Essa experiência de percorrer as aldeias lhe proporcionou vivenciar a exploração e a miséria que seu povo sofria pelo agressivo regime de tutela e o compulsório confinamento que foi imposto aos povos Guarani e Kaiowá de Mato Grosso do Sul.

\begin{abstract}
Sua visão de mundo tinha também algumas semelhanças com a visão fundamentalista da Bíblia. O teko porá (o bom modo de ser) e o teko marangatu (o modo de ser religioso) estão constantemente ameaçados pelo teko vai, que é a maldade, o pecado, as coisas ruins desta terra. Um dia, o mal triunfará, levando à destruição este nosso imperfeito mundo. Só no além - no Yvy Mara e' y, a Terra sem mal - é que se encontrará a felicidade. (PREZIA, 2006, p. 27-28)
\end{abstract}

Desde o início Marçal chama a atenção dos dirigentes da missão Evangélica Caiuá pela sua capacidade de pregação. Para o povo Guarani, a religião é a Palavra Inspirada ${ }^{10}$ e os grandes líderes eram aqueles que, acima de tudo, demonstravam o dom da palavra, da oratória. Dessa forma, por suas qualidades, Marçal acabou sendo então enviado para o Instituto Bíblico Dr. Eduardo Lani na cidade de Patrocínio - MG onde em três anos conclui o curso sobre liderança cristã, e segundo o depoimento da missionária Loide Bonfim Andrade, neste período, "Marçal adquiriu uma vasta cultura bíblica, teve professores de homilética, exegese e aprendeu oratória" (TETILA, 1994, p. 15).

Entre o fim da década de 1940 e meados da década de 1950 mantém contato com Egon Schaden, Darcy Ribeiro e outros pesquisadores, como Roberto Cardoso de Oliveira, trabalhando como intérprete e interlocutor na pesquisa desses antropólogos, pois tinha pleno domínio tanto da língua materna (guarani) quanto da língua portuguesa.

O próprio Tupã'i relatou durante o Seminário sul-mato-grossense de Estudos indigenistas, realizado na Cidade de Campo Grande em 1980, alguns elementos de sua trajetória:

\footnotetext{
${ }^{9}$ O Professor João Pacheco de Oliveira definiu Marçal de Souza com esse conceito - "performático" - em uma conversa informal durante a realização do I Congresso Iberoamericano de Arqueologia, Etnologia e EtnoHistória, realizado pela UFGD na cidade de Dourados em de Maio de 2010.
}

${ }^{10}$ Cf. Clastres, 1993; Chamorro, 2008. 
Primeiramente, eu quero relembrar um pouco do meu passado. Não me lembro bem, porque nós índios, não guardamos datas, como vocês guardam datas e anos no papel. O nosso calendário é o inverno, o nosso correr dos meses é a Lua, o nosso relógio é o Sol. Por isso, não me lembro bem. Se não me engano, na década de 1940, tive o meu primeiro encontro com o professor Darcy Ribeiro. Convivi com ele em suas pesquisas de aldeia em aldeia.

Naquela época, este que fala a vocês, não tinha... não tinha um ideal, não tinha um alvo, não conhecia a própria história.

Em contato com esse grande amigo meu, Dr. Darcy Ribeiro, apesar de não ter quase preparo - mas Tupã, que abre as mentes, abriu a minha mente - reportou-me ao meu passado muito distante. E ali, depois que o Dr. Darcy Ribeiro foi embora, eu revivi a glória de meu povo já muito distante, sendo levado pelos séculos, pelo tempo e pelos anos. Descobri... descobri que nós tínhamos uma riqueza muito grande, uma riqueza muito preciosa, que era a nossa cultura, a nossa crença, a nossa vida de índio, a nossa organização. Desde então, nasceu um amor muito profundo pelo meu povo índio. Desde então, propus em minha vida viver toda a vida, viver entre meus irmãos, para pelo menos sentir seu sofrimento, a sua vida, o seu viver. Então revendo todos, a glória de meu povo já perdida no século, propus, em meu coração batalhar pelo menos pela restauração da nossa cultura, da nossa crença, da nossa organização social, que só nós entendemos (TETILA, 1994, p.19-20).

Essa experiência de vida, conforme o relato anterior, o auxiliou no retorno ao "modo de ser Guarani" (ñande reko), proporcionando assim, gradativamente uma "mudança de consciência” que o levará a uma nova missão, a de batalhar pela cultura, pela religião, pela organização social de seu povo e principalmente pelas demarcações das terras tradicionais. “Deu-se então o que poderíamos chamar de 'segunda conversão', ou 'o caminho de volta ao ser guarani'." (PREZIA, 2006, p. 31). Esse processo é explicado por sua filha Édina de Souza ${ }^{11}$ da seguinte maneira:

Meu pai né... tudo é uma trajetória de vida que ele tem de formação e foi abrindo a consciência dele pra questão indígena... e até essa questão da formação dele que também foi abrindo os horizontes da mente dele pra enxergar a situação que os povos indígenas estavam vivendo e vivem hoje. Que os Guarani estava vivendo, e a questão da violação dos direitos, que através da formação que ele foi tendo acesso a essas outras informações que é da sociedade não-indígena e ele foi comparando e vendo como o povo indígena e o povo Guarani estava sendo violado nos seus direitos.

Torna-se em 1959 auxiliar de enfermagem através de um curso promovido pela OMS (Organização Mundial de Saúde) casando-se também neste ano com uma não-índia, dona Aristídia, com quem teve seis filhos biológicos, criando ainda mais três guachos ${ }^{12}$, adotivos.

(...) atendente de enfermagem do hospital "porta da Esperança", pertencente à Missão, desde os tempos em que o mesmo não passava de um simples ambulatório

\footnotetext{
${ }^{11}$ Entrevista concedida a José Henrique Prado em 20 de maio de 2010 na cidade de Dourados.

12 Para compreender melhor sobre adoção de crianças entre os Guarani e Kaiowá verificar um artigo do Antropólogo Prof. Dr. Levi Marques Pereira, intitulado "No mundo dos parentes: a socialização de crianças adotadas entre os Kaiowá" (PEREIRA, 2002).
} 
médico. A enfermagem, porém, foi a profissão que Marçal aprendeu tanto na prática como na teoria, tendo-a exercido até o fim de sua vida. (TETILA, 1994, p. 17)

Sempre orgulhoso de sua identidade enquanto índio guarani, e sempre encarando a realidade legada a seu povo, aproveitou a oportunidade da inauguração em março de 1963 do Hospital Porta da Esperança, e diante de aproximadamente 800 pessoas faz o uso das seguintes palavras:

$\mathrm{O}$ verde de nossa bandeira que os brasileiros carregavam representava a mata que a civilização nos tirou; vivemos nas terras do governo como párias, esmagados sempre. O amarelo que representa a riqueza do Brasil, a pesca a caça, hoje estão ausentes de nossas terras; tiraram-nos tudo em nome da civilização. $\mathrm{O}$ branco, que simbolizava a paz tão desejada, hoje está ausente do homem. E finalmente, o azul, que representava o céu, na sua beleza florida - estrelas e astros a brilhar -, foi a única coisa que a civilização deixou ao índio, e isso porque ela não pôde conquistar ainda.

Marçal de Souza no I Seminário Sul-Mato-Grossense de Estudos Indigenistas, Campo Grande 1980

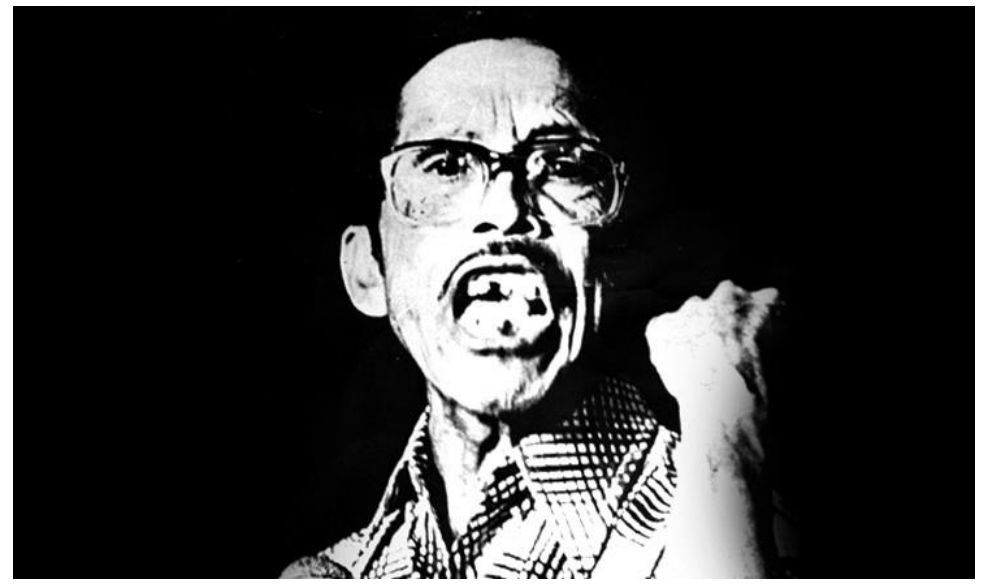

Disponível em: http://memorialdademocracia.com.br/card/cinco-tiros-tombam-o-grande-cacique.

Acesso em: 20 de fevereiro de 2018

Eleito Capitão da Reserva Indígena de Dourados, no mesmo ano (1963) passa a se preocupar com os Guarani e Kaiowá que viviam "desaldeados" e dispersos pelas cidades e fazendas da região, incentivando o retorno dos mesmos para a reserva, pois lá ao menos viveriam entre seus patrícios. Promove também a realização de trabalhos em mutirão dentro da reserva (como a feitura de lavouras e a retomada de práticas religiosas tradicionais). Para relembrar esse tempo utilizo aqui uma fala da filha de Marçal, Édina de Souza, que foi extraída do livro de Benedito Prezia, mas que foi colhida pela equipe do Professor José Carlos S. B. Meihy ${ }^{13}$ :

\footnotetext{
${ }^{13}$ Cf.. MEIHY. José Carlos S. Bom. Canto de morte Kaiowá: história oral de vida. São Paulo: Loyola, 1991.
} 
Em meu tempo de criança, tudo era muito diferente... então o grupo guarani era maior que hoje e havia uma perfeita integração entre todos os índios. (...) Naquele tempo, não havia desmatamento e no meio da mata tudo era melhor. (...) trabalhávamos juntos mediante a um sistema de mutirão e tínhamos um padrão de vida muito melhor que agora...(...) Papai ajudava muito: ele era enfermeiro, pedreiro enfim, era tudo e amigo... Todos gostavam dele e viviam andando atrás dele, consultando-o para isso para aquilo... Pode dizer que ele era uma espécie de cacique... Mesmo os caiouás, apesar de não serem exatamente iguais aos guaranis, vinham sempre à nossa casa e eram tratados como irmãos... quando chegavam os domingos, dia em que os índios têm mais folga, muitos se reuniam em casa, faziam rodas de conversa e eram longas horas discutindo os problemas... Era nesses momentos que meu pai alertava as pessoas sobre o que estava ocorrendo até hoje... É curioso que as rodas não tinham hora nem para começar e nem para terminar... Aliás até hoje tenho problema com esta história de hora marcada. Tudo era espontâneo... o pessoal vinha passear em casa, chegava uma família outra... (...) Era nessas horas que se falava dos problemas da reserva, progresso do branco, dos problemas que estavam sendo provocados... Meu pai sempre se dedicou muito a pensar em como nosso povo deveria se comportar... (PREZIA, 2006, p.34-35).

Esta postura sempre crítica e atenta de Marçal incomodará por demais os interesses dos funcionários do órgão governamental, que tinham mais interesse em "se enriquecer com a venda de madeira e de outros produtos das áreas, do que em defender a comunidade indígena" (PREZIA, 2006, p. 39). E desta forma Marçal de Souza Tupã'i acaba sendo afastado do cargo de Capitão da Reserva Indígena de Dourados no ano de 1972, passando a exercer somente a função de atendente de enfermagem.

Será também neste período que Tupã’i se afastará definitivamente da igreja presbiteriana e consequentemente da Missão Evangélica Caiuá, pois esta não via com bons olhos a prática das festas, cantos e danças da religião tradicional dos Guarani lideradas por Marçal.

Após seu afastamento do cargo de capitão em 1972 é nomeado para assumir seu posto Ramão Silva Machado, de etnia Terena, indicado pelo então chefe do posto Indígena de Dourados Idevar José Sardinha. Esta articulação gerará um cenário propício para a continuidade da indevida exploração e espoliação dos indígenas da Reserva de Dourados. Isso gerou problemas a Tupã'i, pois este parecia não se calar mais diante de uma injustiça. Segundo sua filha Édina de Souza batizada entre os Guarani como Cuñha Pukarandú' ${ }^{14}$ :

Foi na época da gestão desse Sardinha que meu pai sofreu muita agressão, havia uma conivência desse chefe de posto com um grupo Terena que estavam coniventes com a venda de madeira... fizeram a exploração e na época meu pai vinha aqui (Campo Grande) na FUNAI e fazia denúncia da exploração e venda ilegal da madeira.

\footnotetext{
${ }^{14}$ Como Édina de Souza mesmo nos informou na entrevista de 30 de junho de 2010, seu nome de batismo Guarani (Cuñha Pukarandú'i) significaria em uma tradução para o português: "aquela que leva a sabedoria pras pessoas".
} 
Pela sua luta em defesa dos direitos de seu povo Marçal de Souza Tupã'i sofreu injustas consequências ao enfrentar o jogo de poder dessa nova articulação entre Idevar José Sardinha e o novo Capitão Ramão da etnia Terena, pois tinham como práticas o incentivo da monocultura, realizaram uma política de desmatamento da área da reserva, a busca pela "civilização" dos índios, e inclusive prender e aplicar castigos físicos a indígenas da reserva que não correspondiam com os interesses de ambos.

No ano de 1974 Marçal de Souza Tupã'i será agredido, humilhado e ameaçado pelo Capitão Ramão e sua Polícia Indígena, sendo brutalmente agredido enquanto trabalhava no ambulatório do Posto Indígena de Dourados, momento este que Marçal pôde relatar em depoimento concedido ao documentário "Terra de Índio" de Zelito Viana (1978) onde ele explica nessas duas oportunidades:

\begin{abstract}
O caso que aconteceu comigo foi em 1974, no mês de abril, foi dia oito. Mais ou menos nove horas da manhã, eu estava fazendo relatório mensal do movimento do ambulatório para o P. I. quando apareceu um grupo de índios liderados pelo Capitão Narciso, índio Cauiá e também o Capitão Ramão Machado, que é outro Capitão que era braço forte naquela época do encarregado José Sardinha. Chegaram ali, conversaram com o encarregado, com outro Capitão, e foram destacados, mais ou menos dez índios que entraram assim, de sopetão, repentinamente, dentro do ambulatório e, me pegaram como se eu fosse um criminoso, um elemento perigoso. Me pegaram e me rasgaram toda a roupa e ... quase me deixaram nu. E me levaram fora do ambulatório, onde fui espancado pelos outros índios. Eu não culpo índio não, o índio não tem culpa nenhuma. Eles foram subornados pelo Capitão Ramão e pelo encarregado [José Sardinha] para fazer essa injustiça contra a minha pessoa. (TETILA, 1994, p. 27).
\end{abstract}

Eu queria que o povo brasileiro sentisse e visse, através dessa filmagem, a situação real de uma parte do índio brasileiro. [precisamos] conhecer não só os nossos irmãos do Amazonas, que ainda têm área maior, com a possibilidade de locomoverem numa área bem grande, o que é muito lindo. (...) Nós não temos nada disso. Nós índios, que vivemos aqui é que sentimos a injustiça, a pobreza, a perseguição, a fome, porque a área que ocupamos não oferece mais condições para nossa sobrevivência, não temos mais nada! É isso eu quero que chegue ao conhecimento do presidente da República. (PREZIA, 2006, p.52).

Após ser agredido em seu próprio local de trabalho, como relatou acima, a situação na Reserva indígena de Dourados torna-se insustentável devido às frequentes ameaças. Tupã'i acabou por ser transferido para a enfermagem da Casa do Índio em Campo Grande, de onde, algum tempo depois foi dispensado devido as reclamações e denúncias que fazia da falta de condições no atendimento aos índios que por ali passavam. E como era insustentável seu retorno a Dourados foi enviado para a aldeia Tey'i Kuê na cidade de Caarapó, como nos relatou sua filha Édina de Souza ${ }^{15}$ :

\footnotetext{
${ }^{15}$ Entrevista concedida para esta pesquisa em 30 de Junho de 2010 na cidade de Campo Grande.
} 
A FUNAI pra tirar ele daqui [Campo Grande] castigou ele e não mandou pra Dourados, onde tava a família, foi distanciando ele da família... mandou ele pra Tey'i Kuê em Caarapó, lá ele ficou durante cinco anos... e lá ele foi novamente transferido [para Campestre no município de Antônio João-MS] por que ele tava denunciando venda de madeira pelo chefe do posto.

Como verificamos aqui nestes depoimentos, Marçal não se cala diante das práticas hediondas contra seu povo: venda ilegal de madeira, exploração sexual de adolescentes, entre outras:

Em Tey Kuê, onde morava, novamente Marçal se depara com atos de corrupção praticados por agentes da FUNAI. Nessa área indígena, denuncia a venda indevida de madeira, de erva-mate e de gado, e, mais grave ainda, a venda temporária de meninas índias, em idade entre 12 e 15 [para serem exploradas sexualmente. (TETILA, 1994, p. 31).

Em 1978, Tupã'i conhece o trabalho do CIMI (Conselho Indigenista Missionário) do qual se torna aliado, já que a meta desta entidade era apoiar a organização indígena através de assembléias e encontros, sendo esta responsável por diversos laudos e denúncias sobre o desmatamento das reservas, a exploração do trabalho indígena, e ao desrespeito aos direitos desses povos enquanto etnia.

\subsection{Liderança Política}

O apoio do CIMI, que após sua criação convidou Marçal de Souza para ser assessor de saúde, foi fundamental para "ampliar" as palavras de Tupã'i a outros espaços. Primeiramente pelos recursos materiais mínimos que o CIMI tinha condições de proporcionar, somado ao número de denúncias feitas sobre a atuação de funcionários da FUNAI rendeu alguns resultados, como a exoneração do cargo de chefe do Posto Indígena de Idevar José Sardinha.

Foi a partir deste período que Marçal de Souza Tupã'i participou de diversos encontros e assembléias indígenas que culminaram, em julho de 1980, na formação da UNI (União das Nações Indígenas). Percebemos, dessa forma, que a luta promovida por Tupã'i em defesa dos direitos indígenas e das retomadas de terra do povo Guarani, no Estado de Mato Grosso do Sul, tinha pretensões de ser estendida a todos os povos indígenas do Brasil. Como exemplo dessa intenção de projetar-se como uma liderança e um defensor do índio de todo o Brasil, Tupã'i proferiu as seguintes palavras em abril de 1977 na $8^{\text {a }}$ Assembléia de Chefes Indígenas, realizada nas Ruínas de São Miguel no Estado de Rio Grande do Sul: 
próprio índio. Chegamos ai no fim da picada, ao fim da estrada: ou nós avançamos ou nos entregamos ao branco. Esta reunião nasceu da experiência de quem tem um pouco de humanidade, de amor ao próximo. Meus irmãos, chegou a hora de nós levantamos a voz pela sobrevivência de nossa gente, que antigamente foi um povo feliz, um povo despreocupado. Somos um povo que já teve pátria e que não tem mais pátria. Vivemos em terras invadidas, intrusadas. Nossas leis são feitas por pessoal lá de cima, que dizem que nós temos direitos. Nós temos direito no papel, mas onde está na realidade?

Tenho uma cicatriz na minha vida, no meu coração, que nem o tempo nem os séculos vão apagar... Eu estava querendo fazer verão sozinho, como diz o ditado 'uma andorinha sozinha não faz verão'.

Chegou a hora [em] que nós sozinhos não conseguiremos fazer nada. Precisamos nos unir braço a braço, e levantar alto a voz dos nossos antepassados que foram massacrados. Chegou a um ponto que nós os índios devemos tomar a rédea do governo indígena, e esse caminho é o caminho certo: a assembléia, reunir, ouvir todos. Tem noites que não durmo, pensando nos nossos problemas. De esperar nós estamos cansados. Todos aqui temos essa experiência. Nossas reservas estão devastadas, sem madeira, quem tirou? Foi o índio para fazer suas casas? Não, foi o próprio branco. Não podemos ficar mais de braços cruzados. Esta talvez seja a última oportunidade prá nós erguer a nossa tribo, erguer a voz das nossas tribos.

Não é de hoje que eu sonhava com uma assembléia de Índios. É uma coisa maravilhosa. Tem gente que quer que a gente sempre ande com uma 'cangaia' no pescoço... Eu fico emocionado, muito grato a vocês, principalmente a essa gente que está interessada em restaurar nossa tribo, que foi uma grande nação no passado (PREZIA, 2006, p.49-50).

A repercussão de sua fala e luta neste momento já havia alcançado reconhecimento nacional, e por isso Tupã'i foi indicado por várias outras lideranças indígenas que estavam reunidas para este encontro como um dos maiores líderes espirituais do mundo para realizar um discurso de saudação ao Papa João Paulo II em 1980, que estava em visita ao Brasil. Na cidade de Manaus - AM, diante de várias lideranças e representantes indígenas e do Papa João Paulo II, sua fala ganhou o mundo, e transformou-se em uma denúncia da deplorável situação não somente do povo Guarani, mas de todos os povos indígenas no Brasil:

Santidade João Paulo II, eu sou representante da grande tribo Guarani, quando nos primórdios, com o descobrimento dessa grande Pátria, nós éramos uma grande nação e hoje eu não poderia como representante dessa nação, que hoje vive à margem da chamada civilização. Santo Padre, não poderíamos nos calar pela sua visita nesse país.

Como representante, porque não dizer de todas as nações indígenas que habitam este país que está ficando tão pequeno para nós e tão grande para aqueles que nos tomaram esta Pátria.

Somos uma nação subjugada pelos potentes, uma nação espoliada, uma nação que esta morrendo aos poucos sem encontrar o caminho, porque aqueles que nos tomaram este chão não têm dado condições para a nossa sobrevivência, Santo Padre. Nossas terras são invadidas, nossas terras são tomadas, os nossos territórios são diminuídos, não temos mais condições de sobrevivência. Pesamos a Vossa Santidade a nossa miséria, a nossa tristeza pela morte dos nossos líderes assassinados friamente por aqueles que tomam nosso chão, aquilo que para nós representa nossa própria vida e a nossa sobrevivência nesse grande Brasil, chamado um país cristão.

Represento aqui o Centro-sul desse grande país, a nação Kaingang que recentemente perdeu o seu líder; foi assassinado Pankaré, no nordeste. Perdeu o seu líder porque 
quis lutar pela nossa nação. Queriam salvar a nossa nação, trazer a redenção para o nosso povo, mas não encontrou redenção, mas encontrou a morte. Ainda resta uma esperança para nós com a sua visita Santo Padre, o Senhor poderá levar fora dos nossos territórios, pois nós não temos condições, pois nós somos subjugados pelos potentes. A nossa voz é embargada por aqueles que se dizem dirigentes desse grande país. Santo Padre, nós depositamos uma grande esperança na sua visita em nosso país. Leve o nosso clamor, a nossa voz por outros territórios que não são nossos, mas que o povo, uma população mais humana lute por nós, porque o nosso povo, a nossa nação indígena está desaparecendo no Brasil. Este é o país que nos foi tomado. Dizem que o Brasil foi descoberto, o Brasil não foi descoberto não, Santo Padres, o Brasil foi invadido e tomado dos indígenas do Brasil. Esta é a verdadeira história. Nunca foi contada a verdadeira história do nosso povo, Santo Padre. Eu deixo aqui o meu apelo. Apelo de 200 mil indígenas que habitam, lutam pela sua sobrevivência nesse país tão grande e tão pequeno para nós, Santo Padre. Depositamos no senhor, como representante da Igreja Católica, chefe da humanidade, que leve a nossa voz para que ainda a nossa esperança encontre repercussões no mundo internacional. Esta é a mensagem que deixo para o Senhor.

Marçal, o líder Guarani (PORANTIM, agosto de 1980, p. 13).

Este discurso comoveu o Papa João Paulo II, principalmente após saber que foi feito sem uma escrita prévia, sendo pronunciado motivado pelo calor de um Pequeno Deus (Tupã'i) muito indignado com a situação de descaso que acometia os povos indígenas do Brasil. Este discurso repercutiu mundialmente, e desta forma, acabou por gerar outros convites, como a sua participação em março de 1981 em uma conferência promovida pela ONU em Boston - EUA sobre a atuação de mineradoras em terras indígenas.

Através deste sonho, de lutar por todos os povos indígenas do Brasil que Tupã'i se dedicou em ajudar na criação da UNI, formando parte da primeira diretoria. A União das Nações Indígenas se funda com as seguintes intenções:

Representar as nações indígenas e as comunidades que dela vierem participar; promover sua autonomia cultural e autodeterminação; promover a recuperação e garantir a inviolabilidade e demarcação de suas terras; assessorar os indígenas e suas comunidades e nações, no reconhecimento de seus direitos e na elaboração e execução de projetos culturais e desenvolvimento comunitário (PREZIA, 2006, p. 63).

Já na segunda reunião da União das Nações Indígenas realizada em setembro de 1980 na cidade Campo Grande-MS, estando presentes ainda Lino Cordeiro, do povo Miranha, e Raimundo Ferreira, do povo Sateré Maué, os demais participantes eram Guaranis, Kaiowá e Terena, num total de 30 pessoas. Marçal de Souza aproveitou a oportunidade para mais uma vez representar sua vontade de mudança e justiça para os povos indígenas:

O índio tem que reagir. Nós temos que ser malcriados. Se o coronel falar grosso, nós temos que inventar uma voz grossa maior que a dele pra dizer que nós temos direito, nós tamos cobrando o que está dentro do Estatuto do Índio. Nós não fizemos estatuto nenhum, eles fizeram a lei dando direito nosso. Então, tem que cumprir justo e direito. Não podemos baixar a cabeça para fazendeiro, para o 
branco, para o dono da terra, que ele não é dono da terra coisa nenhum. Para o invasor, a borduna da lei em cima dele. Gente do Piracuá não fica quieto não. Vocês não vão ficar quieto. Chama o patrício que está nas fazendas, chama os índios lá, amontoa, faz bastante gente e quando o fazendeiro chegar lá, mete o pau nele. Nós somos os verdadeiros brasileiros (PORAMTIM, agosto de 1980).

A conduta de Marçal de Souza foi considerada como "subversiva" pelo regime da ditadura militar que havia se instituído através do golpe de estado no país desde 1964. Dessa forma, Marçal passa a ser um grande incômodo para as elites agrárias e para o órgão indigenista oficial (FUNAI), sendo perseguido e por diversas vezes incomodado pelas forças repressivas do Estado. Sua filha Édina de Souza nos relatou um desses bárbaros episódios, onde ela afirma que durante os últimos anos de Marçal quando chegou a ser detido como suspeito:

Essa vez que ele veio trazido pela policia aqui pra Campo Grande que ele foi interrogado por 12 horas pela policia Federal foi no mês de Julho, no ano que ele morreu (1983)... em julho de 83... foi no período em que a policia esteve lá e mexeu em tudo nas coisas dele e queria saber dele da onde que ele recebia aqueles jornais de movimento e o Pasquin ... e ele tinha uma aquela coleção "Os miseráveis" de Vitor Hugo, que na época era uma coleção proibida e esses livros todos desapareceram... levaram e queimaram né que na época era o que eles faziam.

A pior agressão foi esse tipo de pressão né... agressão psicológica que fizeram com ele, mas mesmo assim ele não desistiu...ele não desistiu.

Após mudar-se em 1980 para a Aldeia de Campestre no município de Antônio João, Marçal ficou responsável pela enfermaria, continuando sua atividade profissional na área da saúde. Neste período ${ }^{16}$ morava com sua segunda esposa Celina Fernandes Villalba ${ }^{17}$.

É neste contexto e nesta região da fronteira sul do Estado, que Tupã'i travaria, em seus últimos anos (pois foi assassinado em 1983), uma das lutas mais fortes pelo seu povo, a luta pelo reconhecimento e demarcação das terras do Pirakuá, onde vivia um grupo de 30 famílias Guarani e Kaiowá em uma área de mata ainda preservada às margens do Rio Apa, no município de Bela Vista-MS fronteira com o Paraguai. Édina nos descreveu o primeiro contato entre Marçal e a comunidade do Pirakuá:

\footnotetext{
${ }^{16}$ Sua filha Édina de Souza nos informou em uma conversa informal em sua casa na aldeia Jaguapiru (Dourados/MS) dentro da Reserva Indígena de Dourados, que mesmo Marçal estando vivendo com outra esposa ele mantinha uma relação amigável com suas duas esposas, porém neste período Marçal tinha que pedir autorização para sair de Campestre, sendo permitido a ele permanecer apenas dois dias por mês em Dourados, onde ele fazia a compra mensal de alimentos com o salário que recebia da FUNAI.

${ }^{17}$ Infelizmente por limitações no deslocamento não tive oportunidade de realizar pesquisas de campo em Campestre.
} 
Depois que ele foi pra Campestre que ele localizou os índios [do Pirakuá], porque os índios andam muito né... E um índio que veio lá do Pirakuá, que veio pra Campestre atrás de remédio e sabia que tinha um enfermeiro da FUNAI lá... e foi assim que ele começou a contatar com essas famílias.

E começou a escrever pra FUNAI da época aqui [Campo Grande] contando dessas famílias, e que tinha que mandar gente da FUNAI pra lá pra ver... e ai que começou a luta da questão da terra mesmo.

Esse grupo de indígenas estava em conflito com o fazendeiro vizinho, Astúrio Monteiro de Lima, que pretendia expulsá-los dali com o intuito de desmatar e utilizar as terras, declaradas como suas, para ampliar sua área produtiva.

Mais uma vez Tupã'i não se calou, denunciando a situação de conflito em que se encontrava aqueles índios e a urgente necessidade de intervenção do Estado. Escreveu uma carta $^{18}$ ao delegado da FUNAI, a qual não surtiu efeitos maiores:

\author{
Aldeia Campestre, 26 de Outubro de 1980 \\ Ao Coronel Amaro B. Pereira \\ Delegado $9^{\text {a }}$ DR. - FUNAI
}

Mais uma vez venho através desta, fazer apelo a V.S. ${ }^{a}$ no sentido de tomar enérgicas providências a respeito da situação dos índios Caiuás da Aldeia Piraquá no Apa. Pois o arrendatário paraguaio, Romulo Gamarra continua com suas ameaças contra nós. Agora está nos ameaçando de morte abertamente. O mesmo prometeu eliminar os dois principais líderes da aldeia Piraquá, os índios Gentil Barbosa Pereira de Souza e Jacinto Ireno. Visa a minha pessoa e também a pessoa do capitão Alziro que anteriormente estava dando toda cobertura ao paraguaio, ele estava pegando dinheiro do paraguaio para ajudar a expulsar os índios da área do Piraquá. Não conseguindo o seu intento agora está ameaçado também pelo paraguaio Romulo Gamarra. Pois ele, o cap. esteve na área indígena do Piraquá com o paraguaio para tirar de qualquer maneira os índios. Mas os índios estão firmes afim de permanecer na área. Sábado passado estive visitando a área. Os índios estão trabalhando, fazendo muita lavoura de arroz, milho e feijão.

Agora o paraguaio já abriu carreteira até as imediações da aldeia para tirar madeira. $(\ldots)$

Neste momento Tupã'i parece que pressentia que seu fim estava próximo. Vinha sofrendo constantes ameaças por conta da disputa da área do Pirakuá. Sentia-se perseguido como nos relatou sua filha Édina: "Quando foi no mês de agosto [1983] ele voltou em casa e falou assim: 'agora eu tenho certeza de que eu to sendo seguido'(...)”. Mas não esmoreceu em sua luta. Em sua última viagem ao Rio de Janeiro, Marçal participou de um debate realizado pela Associação Brasileira de Imprensa no dia 30 de setembro de 1983, juntamente com o professor Darcy Ribeiro e D. Tomás Balduíno, representante do CIMI. Tupã'i deveria falar sobre a situação indígena do Brasil e, sobretudo, a do Estado de Mato Grosso do Sul. Ele faz

\footnotetext{
${ }^{18}$ Este documento foi coletado no Centro de Documentação Regional, pertencente atualmente à Universidade Federal da Grande Dourados - UFGD, o qual apresenta em seu acervo uma coleção de documentos sobre Marçal de Souza Tupã'i. A maior parte da coleção foi doação do Prof. José Laerte Cecílio Tetila.
} 
um discurso, neste encontro, que mais parece um legado deixado por ele à luta pelos direitos dos povos indígenas:

\begin{abstract}
Mas para onde nós vamos? Neste século chegamos ao fim da picada. Não temos muita alternativa. Não temos mais mata para fugir, nem floresta para nos proteger do perigo, da perseguição, do massacre. É como se estivéssemos à beira de um grande rio, sem canoa, sem ter como atravessar.

Além de sermos os donos primitivos e legítimos dessa terra, temos a lei feita pelos brancos para nos proteger. Mas essa lei não está funcionando. É isso que temos que cobrar do governo que nos deixou no abandono. A lei maior é a natureza... Infelizmente, a lei da natureza é desrespeitada pela lei dos homens.

Estou falando do Rio de janeiro. Apesar de ter visto tantas coisas bonitas feitas pelo branco, fico triste porque meu povo viveu nesta terra antigamente. Aqui começou o sofrimento da nossa gente.

Nós temos grandes amigos aqui, alguns antropólogos, não todos.

Muitos só querem se especializar, lecionar... foram na aldeia, tiraram tudo que nos é sagrado e nos deixaram só com o lixo...

Tenho uma tristeza em minha vida: o fato de ser bastante idoso [63 anos]. Eu queria ser um moço bem novo, com todas as forças que tive em minha juventude. Mas gostaria de ter tido [então] essa consciência, esse amor que tenho em meu coração, agora nessa idade avançada.

Mais levantarão outros que terão o mesmo idealismo, que continuarão o trabalho que hoje nós começamos. Isso eu deixo pra vocês! (PREZIA, 2006, p.74) [destaques nossos]
\end{abstract}

Neste mesmo evento também proferiu essas palavras, que aparentemente indicavam o seu destino enquanto liderança:

Eu sou uma pessoa marcada para morrer. Mas por uma causa justa a gente morre. Alguém tem que perder a vida por uma causa! (PREZIA, 2006, p. 77).

Fato que não demorou a ocorrer. Menos de um mês depois desta fala, mais precisamente no dia 25 de novembro, precedida por inúmeros falas em público a favor da devolução da autonomia, do território (ñande reko) Guarani e Kaiowá e de condições mais justas aos povos indígenas do Brasil. Marçal de Souza Tupã’i foi assassinado em sua própria casa na aldeia Campestre no município de Antonio João. Como relatou sua filha Édina de Souza:

Cinco tiros, um primeiro na boca, que como diz o professor Tetila, é uma forma de silenciar. (...) “cala a boca mesmo”... e quando ele já estava caído no chão, ele já estava praticamente morto deram mais dois tiros, um em cada rim... foi uma violência terrível.

Assim, é muito coerente verificar que a capacidade impressionante de Marçal de Souza Tupã'i em apreender elementos condizentes com as problemáticas enfrentados por seu povo em seus discursos está em alinhamento com as exigências de uma legítima liderança 
indígena Guarani que busca se afirmar para a sociedade que historicamente espoliou e oprimiu os povos indígenas, carregando em suas palavras o clamor de justiça para seu povo. Interessante é o fato que mesmo após serem realizados três julgamentos o crime prescreveu por tempo (25 anos) sendo arquivado por falta de provas contra os suspeitos do assassinato (O dono da fazenda "serra brava" que fazia divisa com as terras do Pirakuá e um capataz contratado pelo fazendeiro) de Tupã'i.

\subsection{Notas Finais: A repercussão da morte de Marçal de Souza}

A repercussão de sua morte foi algo impressionante, divulgada em vários jornais nacionais (Folha de São Paulo, Jornal de Minas, Jornal de Brasília entre outros) e internacionais. O "pequeno Deus” (Tupã’i) Marçal de Souza era uma liderança, que além de estudioso era muito ativo, e mantinha contato por carta com diversas pessoas e instituições no Brasil e fora dele as quais apoiavam a luta pelos povos indígenas do Brasil, e quando souberam de seu assassinato manifestaram apoio e indignação diante de mais este bárbaro crime contra uma liderança indígena no Brasil. A exemplo da fala do primeiro deputado índio do Brasil Mário Juruna:

Quero anunciar esse problema que meu companheiro foi assassinado, matado por alguém e pode ser matado por um político, pode ser matado pelo fazendeiro. Eu não quero condenar quem matou meu companheiro Marçal de Souza: quem matou foi o Presidente da República, quem matou é Ministro do interior, quem matou é FUNAI. (PORANTIM, jan. 1984)

Neste trecho da nota escrita pela Associação Nacional de Apoio ao Índio, do dia 03 de Dezembro de $1985^{19}$ vemos a indignação de outras lideranças:

A ANAÍ denuncia veementemente o descaso da FUNAI, que sempre é a primeira a deixar isolados e a descoberto os líderes indígenas que se destacam na luta pelos direitos de sua gente, tornando-os presa fácil da sanha de terceiros. É o que aconteceu no Paraná com Ângelo Kretã, líder Kaingang de Mangueirinha, e agora, repete-se com Marçal.

Temos, também, o apanhado de depoimentos de índios de todo o Brasil, publicado pelo Jornal Porantim de janeiro de 1984, de Manaus-AM, com falas de Nenito Guarani, Daniel Cabixi (Paresi), João Modesto (Terena), Marta Guarani (sobrinha de Marçal) e Álvaro Tukano como representante da União Nacional dos Índios (UNI):

19 Coletado no Centro de Documentação Regional, situado na cidade Dourados /MS no campus II da Universidade Federal da Grande Dourados - UFGD. 
Meus amigos de Dourados, o que faleceu é meu primo-irmão Marçal de Souza: batizado pelo branco Marçal de Souza; pelo cacique, Tupã'y.

Hoje nós não choramos, mas nosso coração tá chorando por causa da despedida do índio Marçal Guarani.(...) (Nenito Guarani)

A morte de mais um líder indígena de projeção nacional leva a nós índios a refletir profundamente na nossa situação presente.é uma morte perigosa, a refletir a analisar e a tirar conclusões muito precisas sobre a luta do índio no Brasil nos dias atuais. (...) para a gente que esta no poder, para a gente que tem interesse nas terras dos índios, para esses o índio não é palhaço, não é peça de chacota: para esses o índio é o empecilho para o avanço de sua ganância. (Daniel Cabixi da etnia Paresi)

Irmãos, não tenho palavras para poder aqui me expressar diante de uma tristeza que todos os índios, no momento, e o Brasil inteiro sente pela perda de mais um líder de uma comunidade espoliada, roubados seus direitos diante de uma nação que se diz democrática. (João Modesto)

(...) nós é que somos os verdadeiros brasileiros, donos dessa terra. Nós lutaremos juntos, o sangue de meu tio vai levar bem alto essa bandeira em nome da raça Guarani. (Marta Guarani)

Mataram o nosso grande líder indígena, o Guarani Marçal de Souza, o homes que impulsionou a luta indígena no país e que sempre merecerá o nosso respeito pelo trabalho que deixou em nossas mãos.(...) morreu defendendo a terra para os seus irmãos,(...). Vamos fazer de Marçal o herói de nossa luta, porque todos os líderes que os fazendeiros matam nunca serão esquecidos. (Álvaro Tukano)

É claro que Marçal não ficou esquecido para os povos indígenas, como demonstram os depoimentos acima, pois sua força e sua liderança diante da luta na defesa dos direitos dos povos indígenas continua viva, ainda hoje no Brasil.

Marçal não foi a primeira e nem a última liderança indígena assassinada por lutar pelos direitos de seu povo. Para se ter noção da alarmante situação desse momento, expomos aqui uma matéria do jornal Folha de Goiás do dia 29 de Novembro de 1983, quatro dias após a morte de Marçal de Souza Tupã'i, que diz o seguinte:

A morte [de Marçal de Souza] inscreve-se numa longa série de assassinatos de lideranças indígenas do País, só neste ano de 1983, sabemos do assassinato de seis Kaingang em Guarita/RS, (2/6/1983), de Edísio Pataxó Ha-Há-Hae, na Bahia (8/6/83), Alcides Maxacali e Minas Gerais (10/7/83) e dois Xukuru-Karipi em Alagoas (no mês de setembro). Algumas dessas mortes foram praticadas com requinte de crueldade como o do índio Alcides Maxacali, que depois de morto, teve as orelhas cortadas, mantendo uma tradição bárbara que persiste desde o início do século passado, em que o assassino comprova seu crime apresentando ao mandante, como recibo, as orelhas das vítimas. Em todos esses casos nenhum dos assassinatos foi preso.

Alarmante é o fato de que hoje os Guarani e Kaiowá de Mato Grosso do Sul ainda permanecem em constantes conflitos pela retomada de suas terras e pela reorganização de 
seus tekoha. Ou seja, o motivo da morte de Marçal de Souza, continua sendo uma questão em aberto em nossa região, sem perspectivas de solução.

\begin{abstract}
Em 29 de outubro de 2009, um grupo de índios Guarani tentou entrar na terra conhecida como Ypo'i, ocupada pela fazenda São Luiz, em Paranhos [MS]. Um dia depois, foram surpreendidos por um grupo de pistoleiros que capturou dois professores indígenas, Rolindo e Genivaldo Vera. O corpo de Genivaldo foi encontrado na beira de um córrego, dias depois. O corpo do primo dele, Rolindo, ainda não foi encontrado.

"Pelo menos o cadáver, os ossos, eu ainda tenho esperança de achar. Meu filho morreu lá porque o sonho dele era ter essa terra. A terra não é dos fazendeiros, é nossa", desabafa Tila Ximenes, mãe de Rolindo. Em busca do corpo dele, e para pressionar pela demarcação da terra, o grupo voltou a entrar na fazenda em agosto [2010]. Até o fechamento desta edição, resistiam no local, apesar do cerco dos pistoleiros. (CAROS AMIGOS, outubro 2010, ano XVI, nº 51, p. 05)
\end{abstract}

Em novembro de 2009, pela quarta vez desde 2007, um grupo kaiowá de cerca de 250 indígenas ocupou a terra tradicional de Kurusu Ambá, de onde relatam terem sido retirados nos anos 1970. A área fica próxima a Coronel Sapucaia [MS], na fronteira com o Paraguai. Passaram a ser sistematicamente ameaçados por grupos de pistoleiros, com tiroteios diuturnos. Um mês depois, o corpo de do jovem de 15 anos Osmair Fernandes foi encontrado com marcas de tortura e espancamento. Até hoje, o caso não está esclarecido. Meses antes, em maio, o líder Ortiz Lopes tinha sido morto. (CAROS AMIGOS, outubro 2010, n 51, p. 06)

E assim continua a ser escrita a história de violência e agressões contra os Guarani e Kaiowá de Mato Grosso do Sul, através de relações de desrespeito, assassinatos e injustiça.

\title{
3. Referências
}

BRAND, Antonio J. O impacto da perda da terra sobre a tradição Kaiowá/Guarani: os difíceis caminhos da Palavra. Tese de doutorado, História da PUC/RS, 1997, 382 p.

CARDOSO DE OLIVEIRA, Roberto. A Sociologia do Brasil Indígena. Rio de Janeiro: Tempo Brasileiro, 1972.

CHAMORRO, Graciela. Terra Madura, Yvy Araguyje: Fundamentos da Palavra Guarani. Dourados, MS: UFGD, 2008.

CLASTRES, Pierre. Crônica dos índios Guayaki: o que sabem os Aché, caçadores nômades do Paraguai. Traduzido por Tânia Stolze Lima e Janice Caiafa. Rio de Janeiro: Editora 34, 1995.

CLASTRES, Pierre. La palabra luminosa: mitos y cantos sagrados de los guaraníes. Buenos Aires: Ediciones del Sol, 1993.

CONSELHO Indigenista lança manifesto sobre a morte do índio Marçal. Folha de Goiás, Goiânia, 29 nov. 1983.

MONCAU, Joana; PIMENTEL, Spensy. O genocídio surreal dos Guarani-Kaiowá. Caros Amigos, São Paulo, nº 51, p. 4-7, out. 2010. 
PEREIRA, Levi Marques. No mundo dos parentes: a socialização das crianças adotadas entre os Kaiowá. In: LOPES DA SILVA, Aracy et al. (orgs.). Crianças indígenas: ensaios antropológicos. São Paulo: Global, 2002, pp. 168-187.

PREZIA, Benedito. Marçal Guarani: a voz que não pode ser esquecida. São Paulo: Expressão Popular, 2006.

SCHADEN, Egon. Aspectos fundamentais da cultura Guarani. $3^{\text {a }}$ Edição. São Paulo: Editora da Universidade de São Paulo, 1974.

SOUZA, Marçal de. Intervenção de Marçal na assembléia da UNI. PORANTIM, Manaus, ago. 1980b.

SOUZA, Marçal de. Líder Guarani: "Somos nações subjugadas". PORANTIM, Manaus, ago. 1980a.

TETILA, José Laerte Cecílio. Marçal de Souza Tupã'I: um guarani que não se cala. Campo Grande: Editora UFMS, 1994. 